\title{
Application of Electromagnetic and Electrical Resistivity Methods for Borehole Siting in Low-Grade Metavolcanic and Metasedimentary Rocks, Sunyani West, Ghana
}

\author{
Alfred K. Bienibuor ${ }^{1 *} \quad$ Kwasi Preko $^{2} \quad$ Akwasi A. Aning $^{2} \quad$ Mary Antwi $^{3} \quad$ Ismaila Emahi $^{1}$ \\ 1.Department of Chemical Sciences, University of Energy and Natural Resources, P. O. Box 214, Sunyani, \\ Ghana \\ 2.Department of Physics, Geophysics Section, Kwame Nkrumah University of Science and Technology, \\ Kumasi, Ghana \\ 3.Department of Environmental Management, University of Energy and Natural Resources, P. O. Box 214, \\ Sunyani, Ghana
}

\begin{abstract}
This paper employs the electromagnetic (EM) and the electrical resistivity methods for siting boreholes for communities in the Sunyani-West district of Ghana, a terrane comprising a mixture of granites and low-grade metavolcanic and metasedimentary rocks. These communities which depend on groundwater for livelihood have over the past few decades been hit by drastic seasonal irregularities in rainfall, making it imperative to seek an alternative source of potable water (preferably groundwater). Measurements to locate sites for boreholes were made by employing the Geonics EM-34 conductivity meter. In addition, co-located measurements were made with the ABEM SAS 1000C Terrameter in the Schlumberger electrode array configuration. Results of the measurements showed that each community could have at least two borehole sites with a high potential for groundwater extraction. The overburden of selected sites varied for the communities and ranged from 40 to $67 \mathrm{~m}$. However, recommended drilling depths at these sites were $60 \mathrm{~m}$ for Adwinsa community, $70 \mathrm{~m}$ for Akurakan community and $60 \mathrm{~m}$ for Nana Ameyaw community. Test boreholes sunk at respective depths of $45 \mathrm{~m}, 55 \mathrm{~m}$ and $68 \mathrm{~m}$ in Adwinsa, Nana Ameyaw and Akurakan had yields of $12 \mathrm{~m}^{3} / \mathrm{h}(200 \mathrm{l} / \mathrm{min}), 24 \mathrm{~m}^{3} / \mathrm{h}(4001 / \mathrm{min})$ and 1.14 $\mathrm{m}^{3} / \mathrm{h}(19 \mathrm{l} / \mathrm{min})$ respectively. In all three communities the aquifer was intercepted in phyllite bedrocks.
\end{abstract}

Keywords: aquifer, groundwater potential, borehole, electrical resistivity, vertical electrical sounding, conductivity

DOI: $10.7176 / \mathrm{JEES} / 10-10-05$

Publication date:October $31^{\text {st }} 2020$

\section{Introduction}

The problems associated with accessibility of quality drinking water is a global issue (Watkins, 2006; Srinivasan et al., 2012). It is not a surprise that the United Nations has declared the right to access of safe drinking water as a fundamental human right (Dinka, 2018). According to Jury and Vaux (2007), water crisis inhibits development and affects human's quality of standard of living. It results in poor health, especially, for the poor and vulnerable (Ugya et al., 2018), low educational standard and poor agricultural production. Even though the world has already met the Millennium Development Goal (MDG) target of halving the proportion of people without sustainable access to safe drinking water in 2015 (UNICEF/WHO, 2012), accessibility to quality drinking water is still a major challenge (Dinka, 2018). In Ghana, the pressure on the water supply systems is overwhelming, due to the continuous increase in population. A number of Ghanaian communities continue to depend on unsafe water sources such as ponds, rivers and lakes.

Surface water pollution is pervasive, causing a drastic reduction of the volume of potable water for use by the ever-increasing population. It is thus time Ghana turned its attention to the groundwater resource which is generally considered purer and needs less treatment. Across the globe groundwater is, historically, the main source of water that has sustained life for centuries (Fienen and Arshad, 2016). Apart from the fact that it is less prone to pollution as compared to surface water sources, the impact of drought, and long dry seasons in some cases, on groundwater is minimal (MacDonald et al., 2001).

Although groundwater is a hidden natural resource, it is possible to delineate potential groundwater sites with the use of the relevant geophysical and geological techniques (Siemon et al., 2009). It is accumulated and stored in the subsurface in geologic structures in rocks, referred to as aquifers. Groundwater development is generally cheap and long lasting with low level of contamination. More than half of the world's population depends on groundwater for daily water needs. About $50 \%$ of the United States public water supply comes from groundwater (Dieter et al., 2018). In Ghana about $52 \%$ of the citizenry use groundwater as source of potable water (GyauBoakye and Dapaah-Siakwan, 2004).

The electrical resistivity technique has been used in many instances across the globe for groundwater, mineral and geotechnical investigations, resulting in successful outcomes. For example, Jayeoba and Oladunjoye (2015) 
used this to examine the hydrogeological potential in hard rocks in a housing estate, Sathish et al. (2011) and Acworth and Dasey (2003) used it in mapping seawater intrusion into aquifer systems, Nyquist et al. (2008) employed it to examine groundwater discharge into streams and Sikah et al. (2016) made use of it in mapping groundwater potential sites.

A survey of the communities of Adwinsa, Akurakan and Nana Ameyaw in the Sunyani West District, suggests that there are serious problems with accessibility to potable water. Sources of water in these communities are streams (some of which are ephemeral), and a privately owned hand-dug well in Adwinsa. Drinking water from such sources leaves inhabitants vulnerable to all kinds of diseases. This paper employs the use of the electromagnetic and the electrical resistivity methods to help locate suitable borehole sites for tapping groundwater for these communities. The choice of these two methods is based on their suitability and successes chalked by a number of researchers with these methods. This is the first instance such methods are being employed to assess the suitability of siting boreholes at the study site.

\section{The Study Area}

Measurements were carried out in the three communities of Adwinsa, Akurakan and Nana Ameyaw (Fig. 1) in the Sunyani West District in the Bono Region of Ghana. The Sunyani West district lies between latitudes $7^{\circ} 19^{\prime} \mathrm{N}$ and $7^{\circ} 35^{\prime} \mathrm{N}$ and longitudes $2^{\circ} 08^{\prime} \mathrm{W}$ and $2^{\circ} 31^{\prime} \mathrm{W}$. It has a mean monthly temperature of about $26^{\circ} \mathrm{C}$ with an annual average rainfall of about $1700 \mathrm{~mm}$. The district's climate falls within the wet semi-equatorial zone of the country; hence rainfall is bimodal with the major season starting from April and ending in July and the minor season starting from September and ending in October. The Sunyani West District and its environs are geologically underlain by the Birimian and Dahomeyan Precambrian rocks, with the Birimian rocks believed to be interspersed with large masses of granite. The Birimian rocks however, dominate over the Dahomeyan rocks. The Birimian formation principally houses most of the economic mineral deposits in the country. Examples include gold, diamond, bauxite, iron and manganese. Major Birimian rock types include slate, phyllite, schist, tuff, lava, greywacke, pyroclastic rocks and amphibolites (Kesse, 1985). These rocks are folded, foliated and interconnected with fractures, faults, bedding and cleavage planes which occur due to high intensity of weathering or tectonic activities. These structures are suitable for groundwater development. Hence, the probability of drilling a productive borehole in the basement complex is high, especially with the application of appropriate geophysical tools. About $90 \%$ of boreholes drilled in the country are located in the Birimian formation with its associated granitoids (Dapaah-Siakwan and GyauBoakye, 2000). Boreholes in the Birimian rocks have an average yield of about $12.7 \mathrm{~m}^{3} / \mathrm{h}(211.71 \mathrm{l} / \mathrm{min})$, at depths varying between 34 and $62 \mathrm{~m}$.

A visit to 10 randomly selected rural communities and the four major towns (Odomase, Fiapre, Kyiraa and Nsoatre) in the district, coupled with information sourced from the Community Water and Sanitation Agency (CWSA), suggests that about $80 \%$ of the people of this district depend on wells. Apart from the major towns of the district where some dwellers are connected to the Ghana Water Company's grid, the district basically depends on groundwater through hand dug wells. Many houses in the district, including the major towns, have private wells. Few people can afford the sinking of boreholes. And many depend on surface water sources including rivers, lakes, ponds and streams. 


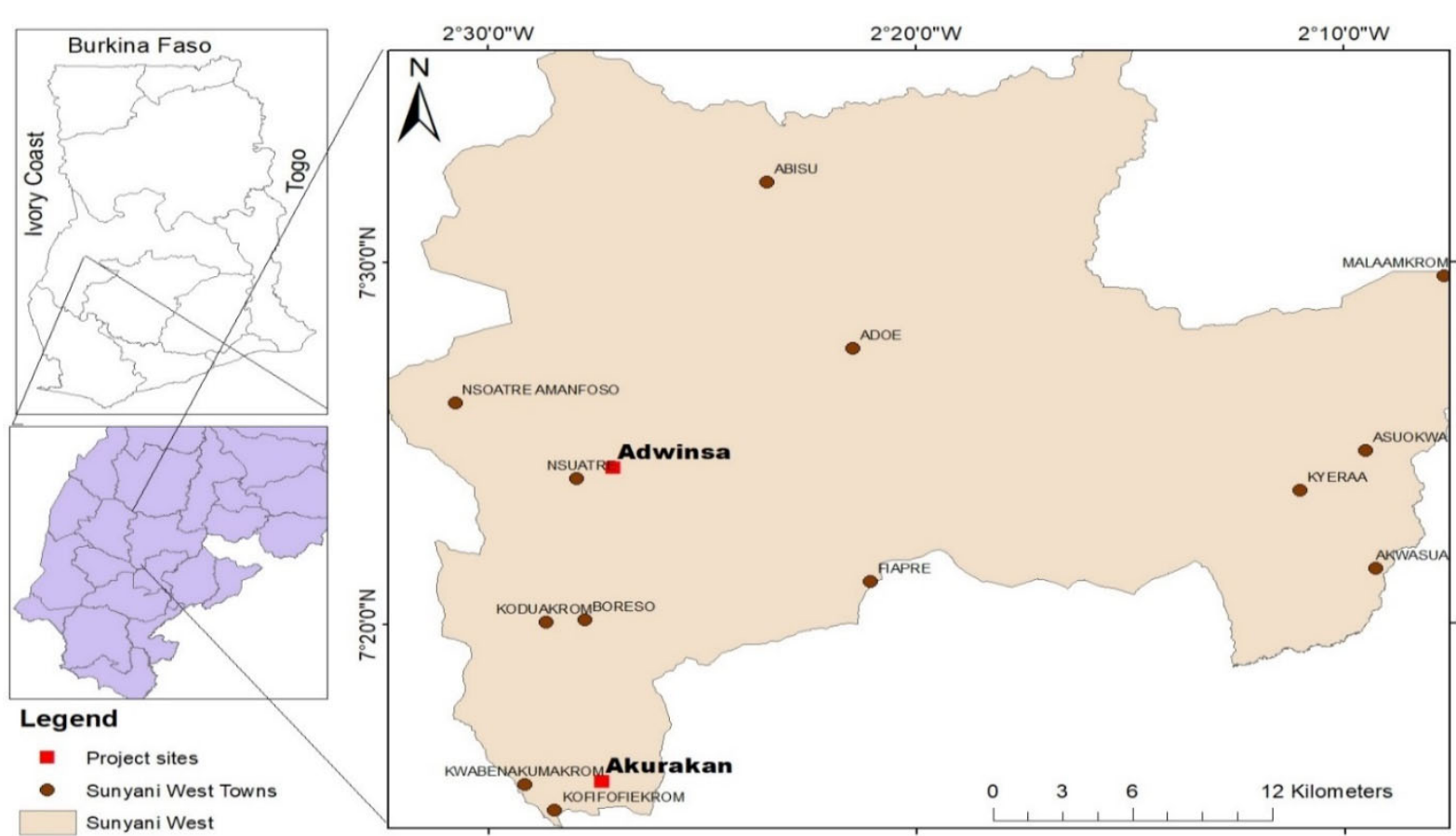

Fig. 1: A map of Sunyani West district showing Adwinsa and Nkurakan.

\section{Instrumentation and Methods}

Two geophysical tools, Geonics EM 34-3 and the ABEM SAS 1000C terrameter, were used for the data collection. The Geonics EM 34-3 was used for profiling to provide useful information on possible areas of linear features like fractures, faults or joints while the ABEM SAS $1000 \mathrm{C}$ terrameter was used for vertical electrical sounding at selected points along the EM profiles.

\subsection{The Geonics EM 34-3}

The Geonics EM 34-3 is designed to directly measure linear conductivity under given conditions. Primary and secondary magnetic fields are measured and compared. The ratio of the primary field to the secondary field, $\mathrm{H}_{\mathrm{s}} / \mathrm{H}_{\mathrm{p}}$ is directly proportional to the apparent conductivity $\left(\sigma_{a}\right)$, and this relationship holds only for low to moderate conductivities. It consists of two coils - the transmitter and receiver coils - and operates in both vertical and horizontal modes. It is therefore sensitive to both vertical and horizontal geological structures. The two coils are linked to each other with cables of specified lengths: $10 \mathrm{~m}, 20 \mathrm{~m}$ and $40 \mathrm{~m}$. Each of these cable lengths or intercoil spacing has a defined depth of probe. For instance, the maximum depth of probe for the $20 \mathrm{~m}$ cable is $15 \mathrm{~m}$ in the horizontal dipole (HD) mode and $30 \mathrm{~m}$ in the vertical dipole (VD) mode. For the $40 \mathrm{~m}$ cable it is $30 \mathrm{~m}$ in the $\mathrm{HD}$ mode and $60 \mathrm{~m}$ in the VD mode. Hence, for the HD mode the depth of probe is 0.75 times the cable length and 1.5 times the cable length for the VD mode.

\subsection{The ABEM SAS $1000 \mathrm{C}$ Terrameter}

The ABEM SAS 1000C terrameter is an efficient data acquisition tool with inbuilt Lund Imaging System for resistivity, spontaneous potential and induced polarization measurements. It has an inbuilt electrode selector and GPS, which automatically selects and logs the loci of targets during surveys. Several protocols can run on the same traverse, and even as the measurement is being done, data quality can be monitored on the colour display screen. Data is displayed either as curves or pseudosections.

The transmitter is either powered by a clip-on battery pack or an external power source. The instrument is designed to automatically take consecutive readings and continuously average these and store the results.

Table 1: Typical resistivity values for different water types (Telford et al., 1990):

\begin{tabular}{lc}
\hline TYPE OF WATER & RESISTIVITY $[\mathbf{\Omega m}]$ \\
\hline Meteoric waters & $3.0 \times 10^{1}-1.0 \times 10^{3}$ \\
Surface waters & $1.0 \times 10^{-1}-3.0 \times 10^{3}$ \\
Soil waters & $1.0 \times 10^{1}-1.0 \times 10^{2}$ \\
Natural waters & $5.0 \times 10^{-1}-1.5 \times 10^{2}$ \\
Sea waters & $1.0 \times 10^{0}-1.0 \times 10^{2}$ \\
\hline
\end{tabular}

The prospecting sequence carried out consisted of three stages, namely: reconnaissance survey (terrain evaluation), geophysical data acquisition and data processing. The electromagnetic and electrical methods 
designed features such as fractures and joints which are suitable for groundwater development and retention (Ndlovu et al., 2010).

\subsection{Reconnaissance Survey}

Terrain evaluation is an inherent part of groundwater prospecting. It is designed to identify surface geological and physiological features such as existing boreholes, hand-dug wells, streams and their flow pattern characteristics of water bearing formations. This survey was carried out first before the geophysical data collection. Information was also sought from the community to help isolate distinct places such as cemeteries, waste site deposits and places of convenience.

\subsection{EM data collection}

The electromagnetic data was collected using the Geonics EM 34-3 conductivity meter. Measurements were taken with the $20 \mathrm{~m}$ inter-coil cable at $10 \mathrm{~m}$ intervals along survey profiles in both the horizontal and vertical dipole modes at each station.

Three profiles were traversed in the three communities where data interpretation indicated potential zones of fracturing, jointing or faulting. Areas of particular interest were zones with high conductivity at depth which were indicated by values of electrical conductivities in the vertical modes being greater than that of the horizontal mode (Beeson and Jones, 1988) and weathered zones which have high potential for groundwater accumulation (Fig. 2).
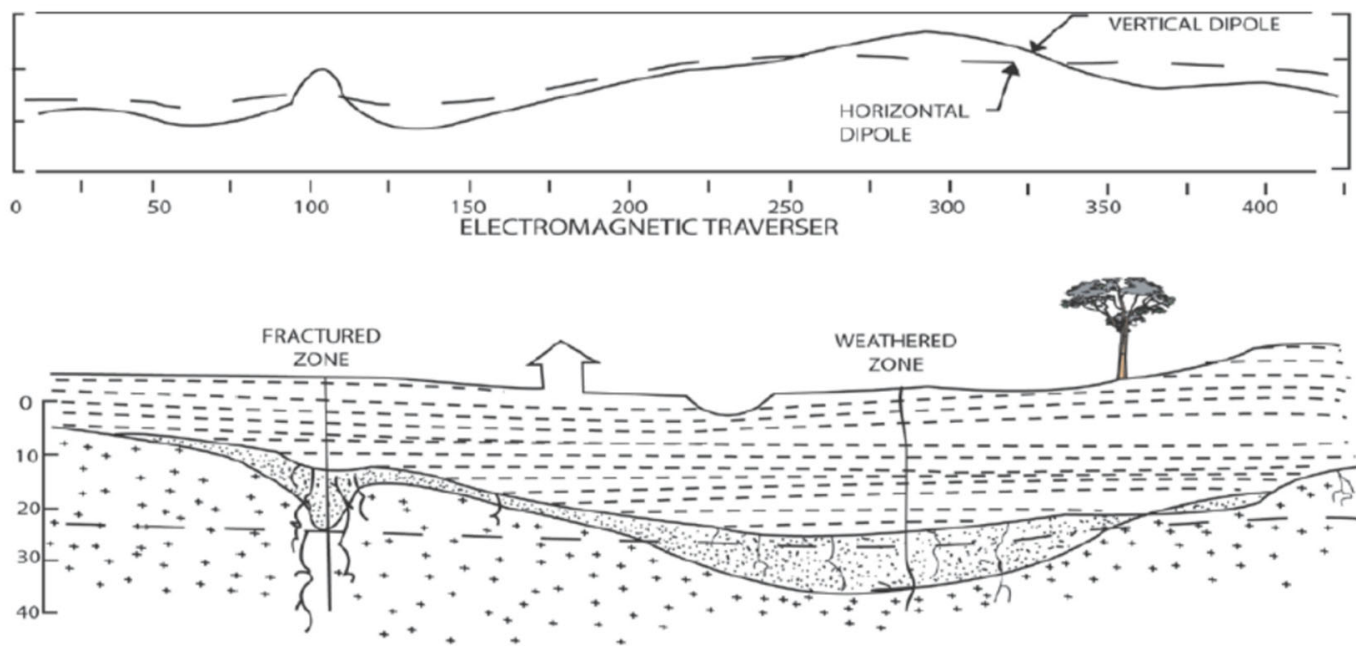

DESCRIPTION

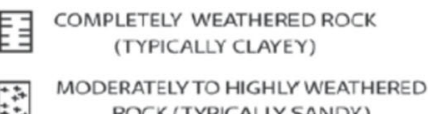

Fig. 2 Model showing fractured and weathered zones (Modified after Palacky et al., 1981)

\subsection{Resistivity data collection}

Co-located measurements, using the Vertical electrical sounding (VES) mode in the Schlumberger protocol were carried out with the ABEM SAS 1000 C Terrameter.

\subsection{Data processing}

Golden Software Grapher 14 and ZondIP2 version 5.1 software were used to model the EM and the VES data respectively. Information contained in these models were then interpreted based on identifiable geological features like fracturing, jointing, and the like. Fractured or weathered zones with high potential for groundwater accumulation were seen on the apparent conductivity-distance plots as sharp positive peaks representing "necks" or cross-over points of deeper electromagnetic responses and shallower responses (Chegbeleh et al., 2009) (Figs. 3,4 and 5).

\section{Results and Discussion}

\subsection{Result from the EM Survey}

The graphs (Figs 3, 4 and 5) indicate the electrical conductivities of the subsurface at Adwinsa, Akurakan and Nana Ameyaw respectively. For the horizontal coplanar mode (HD mode), the graphs indicate electrical 
conductivities at shallower depths of up to $15 \mathrm{~m}$ while that of the vertical coplanar mode (VD) indicate deeper depths of up to $30 \mathrm{~m}$. It is worth noting that high conductive peaks are possible fracture zones, which are major indicators of the presence of groundwater. In this wise terrain conductivity could be as a result of buried conductive bodies like the water table, ions, gold or metallic minerals (Chegbeleh et al., 2009) in the subsurface. From the graphs peaks of the VD overriding that of the HD were carefully selected for a validatory survey for the occurrence of groundwater using VES method (McNeill, 1980). The next section discusses the results of the ground electromagnetic survey from a few communities.

\subsubsection{Results of Soil conductivity survey from the Adwinsa community}

The apparent conductivity of the subsurface was between 2 and $13 \mathrm{mS} / \mathrm{m}$ in the HD mode and 2 and $14 \mathrm{mS} / \mathrm{m}$ in the VD mode (Fig. 3). Both crossovers and necks were recorded on this profile. Four crossovers (A, B, C and D) were recorded at $0,170,300$ and $310 \mathrm{~m}$ along the profile, while four necks (I, J, K and L) were recorded at 20, 50, 60 and $270 \mathrm{~m}$. Generally, a crossover is a more promising groundwater zone than a neck (Anechana et al., 2015), hence two of the crossover points (B and C) were selected for VES sounding.

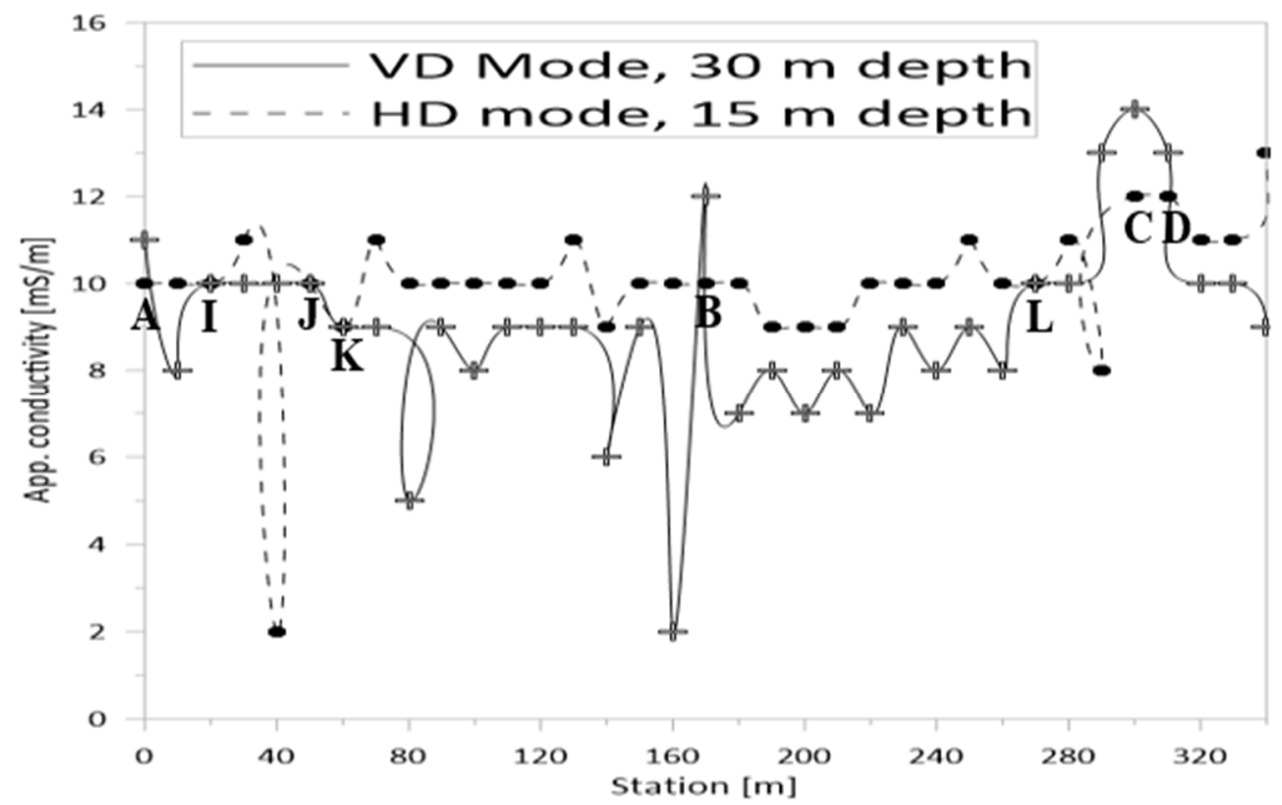

Fig. 3: Conductivity profile at Adwinsa

\subsubsection{Results of Soil conductivity survey from the Akurakan Community}

In this community graphs in the VD and the HD modes showed signs of potential decay, an indication of aquiferous rocks at depth. Apparent conductivity of the subsurface ranged between 4 and $20 \mathrm{mS} / \mathrm{m}$ in the HD mode and 2 and $10 \mathrm{mS} / \mathrm{m}$ in the VD mode (Fig. 4). Crossover points (A and B) were recorded at stations 50 and 80 with no necks. These two crossover points were therefore selected for further analysis with the electrical resistivity method. The subsurface conductivity, together with the nature of the EM graphs plotted, suggested moderate to high groundwater potentials in this community. 


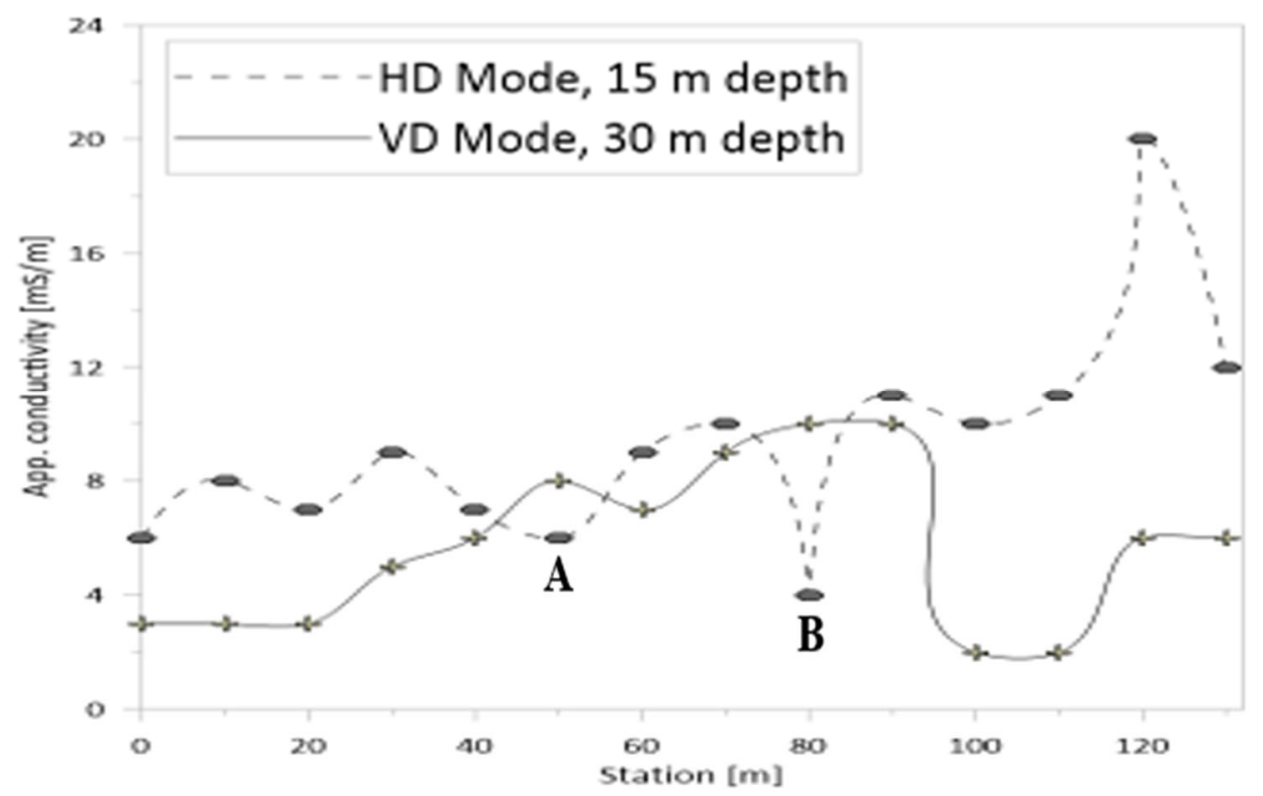

Fig. 4: Conductivity profile at Akurakan

4.1.3 Results of Soil conductivity survey from the Nana Ameyaw Community

Groundwater potentials in this community were expected to be higher than the other two communities. This is because ground conductivity measurements of the subsurface showed that it was generally highly conductive. Though this could be due to other factors, the possibility of the conduction emanating from groundwater was expected to be high. In the HD mode conductivity values ranged from 3 to $6 \mathrm{mS} / \mathrm{m}$ and 2 to $7 \mathrm{mS} / \mathrm{m}$ in the VD mode. These modal graphs decayed at the ends, suggesting fracturing and aquiferous nature of rocks at depth. Two crossover points (A and B) and three necks (I, J and K) were recorded at the end of the survey. The two crossover points were selected for further analysis.

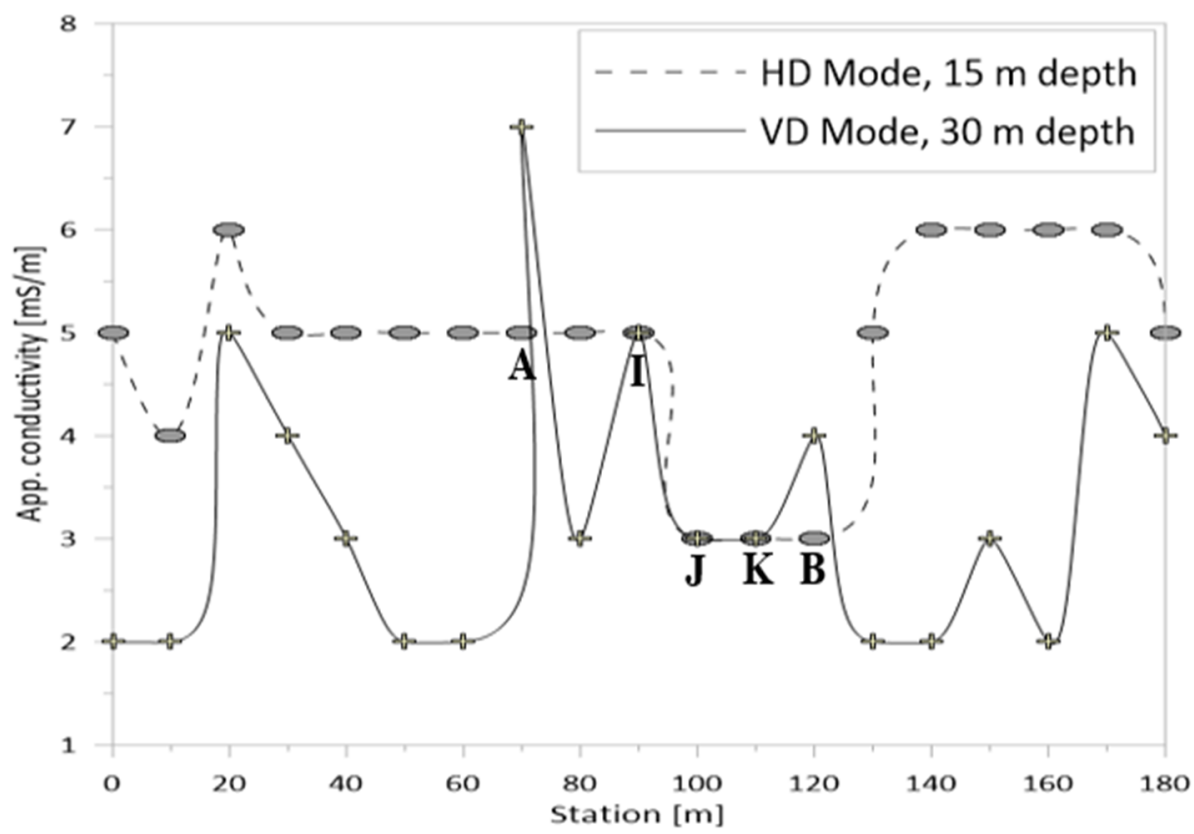

Fig. 5: Conductivity profile at Nana Ameyaw

\subsection{Results from the Resistivity Survey}

The resistivity data was used to validate the electromagnetic data and to locate the best points for drilling. The Zond geophysical software (zondIP2 version 5.1) was used to process the resistivity data. The data was processed into modelled curves, showing the number of layers, the layer thicknesses and the depth of burial to each layer as well as the resistivities of the layers. The layer resistivities were compared with standard fresh groundwater resistivity values ranging from 10 to $100 \Omega$ m (Loke, 2000).

VES points with appropriate layer thicknesses or reasonable overburdens (depth to the basement rock) and 
appropriate bedrock resistivities were selected for drilling, taking into particular account the geology of the area and the interests of opinion leaders in the community.

The models obtained clearly indicated a wide variation in the subsurface resistivity. The resistivities of the soils and rocks of the subsurface were basically governed by the amount of pore fluids (e.g. water, oil or gas) and the hydraulic permeability. High variations in subsurface resistivity at different depths suggested the presence or otherwise of anomalous bodies such as, minerals, buried objects or fluids (Kumar, 2012); though different soil types, variations in soil moisture, variations in electrode ground coupling, for example, could also cause variations in the subsurface resistivity significantly. The next section takes a look at the individual results from the communities.

\subsubsection{Results of soil resistivity survey from the Adwinsa community} VES Point A170, Adwinsa

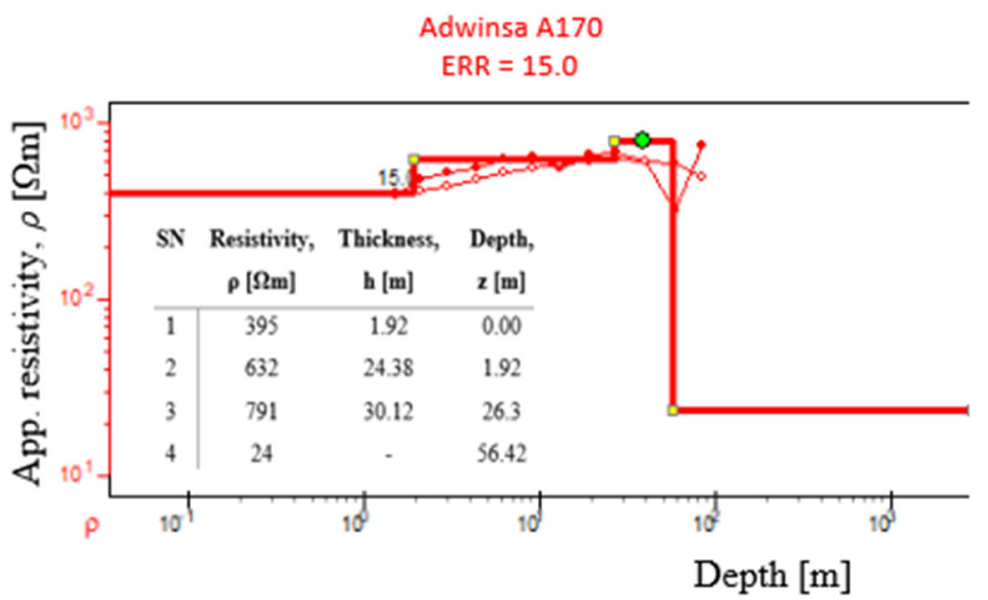

Fig. 6: VES modelled curve for station A170, Adwinsa

The nature of the graph and the bedrock resistivity (Fig. 6) are indications of good groundwater potential at this location. With the low bedrock resistivity of $24 \Omega \mathrm{m}$, the chances of drilling a wet borehole are high (Olasehinde and Bayewu, 2011). Though the subsurface conductivity/resistivity distribution depends on clay content, water and other buried conductive bodies (Siemon et al., 2009), groundwater is more likely to contribute to the low resistivity value of the bedrock recorded here as the study area is underlain by Birimian rocks (Kortatsi and Quansah, 2004). The resistivity values of the overlying layers of the aquifer are all moderately low, hence the overburden could comprise unconsolidated or moderately hard rocks. This could enhance recharge of the aquifer on one hand and pollution from surface waters and surface-runoff on the other (Grinevskii, 2014).

VES Point A300, Adwinsa

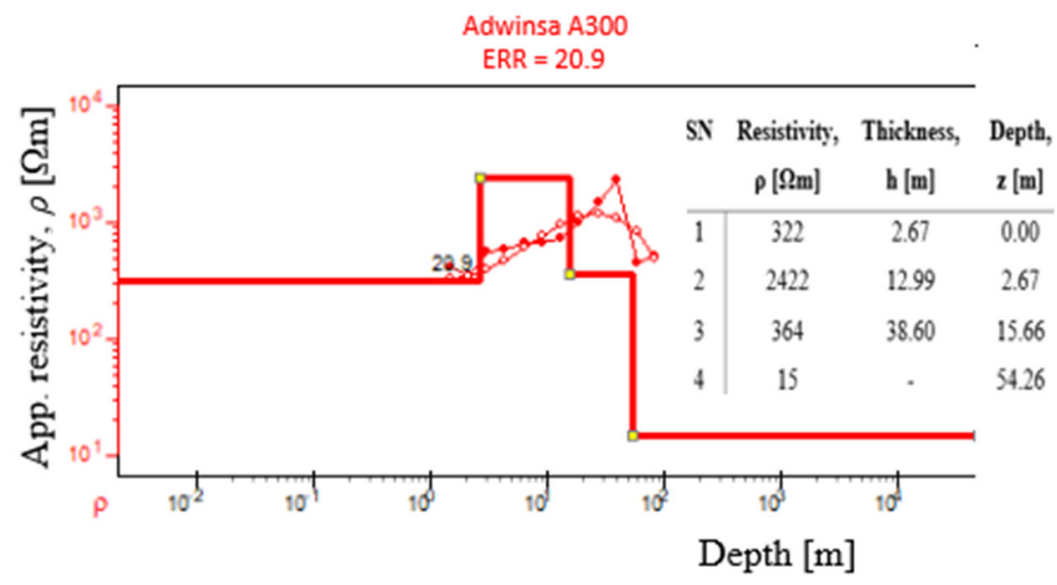

Fig.7: VES modelled curve for station A300, Adwinsa

This VES point was suitable for borehole drilling. Four soil layers were uncovered with their resistivities, depths and thicknesses indicated in Fig. 7. The bedrock resistivity of $15 \Omega \mathrm{m}$ is within the typical soil water resistivity range of 10 to $100 \Omega \mathrm{m}$ (Table 1) and it is thus, expected to be fractured (Telford et al., 1990). According to Muchingami et al. (2012), rock resistivities below $50 \Omega \mathrm{m}$ indicate good groundwater potentials. Coupled with the fact that the graph has a sharp decaying curve, which suggests low resistivity values arising from fractured or porous rocks at deeper depths, the groundwater potential at this point was expected to be high (Manu et al., 2019). Additionally, the high resistivity of the second layer $(2422 \Omega \mathrm{m})$ suggests a massive, unfractured rock with less 
possibility of groundwater structures. This is an added advantage for the site because the second layer could serve as a caprock to the aquifer (Buttinelli et al., 2011; Park et al., 2016), to help minimize pollution from surface water and runoff (Vilarrasa et al., 2011). A $60 \mathrm{~m}$ depth was recommended for drilling; however, the borehole was drilled to a depth of $45 \mathrm{~m}$ with a yield of $12 \mathrm{~m}^{3} / \mathrm{h}(200 \mathrm{~L} / \mathrm{min})$. The overburden was composed of laterite with reddish topsoil, and the bedrock was intercepted on weathered phyllites with some quartz.

Though the two VES points (A170 and A300) in this community were both suitably located and showed signs of good groundwater prospects, station A300 was ranked above A170 for drilling because the larger overburden of A300 could serve as a better caprock to the aquifer to minimize water pollution in the long term. Hence, station A300 was drilled instead of A170.

\subsubsection{Results of soil resistivity survey from the Akurakan community VES Point A50, Akurakan}

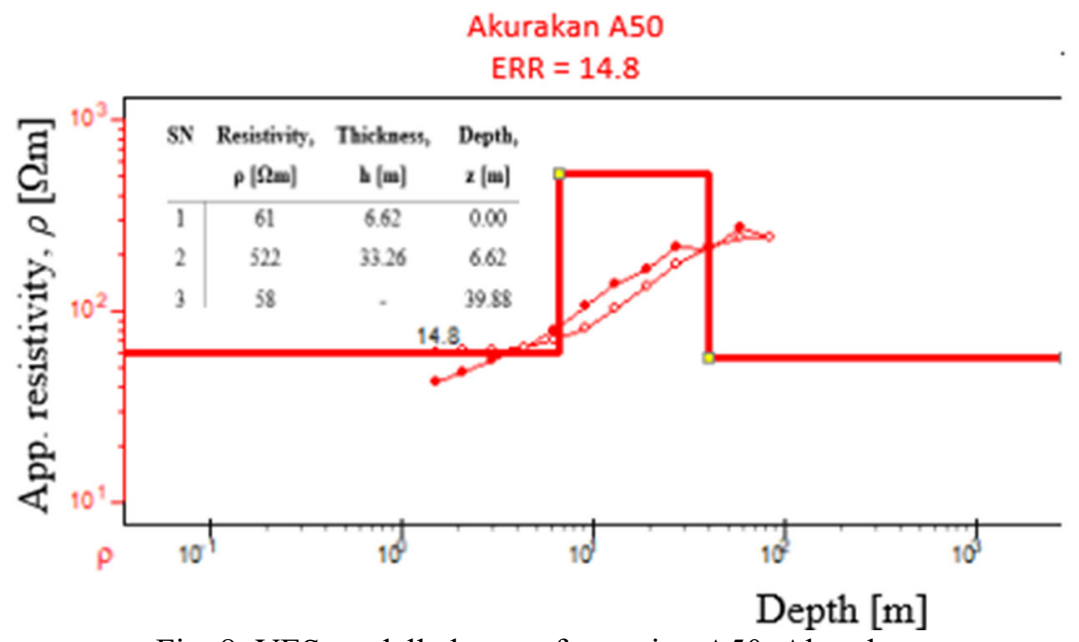

Fig. 8: VES modelled curve for station A50, Akurakan

Three subsurface layers were uncovered at this VES point (Fig. 8). Groundwater development in the third layer could be good due to its resistivity of $58 \Omega \mathrm{m}$ which is within the acceptable groundwater resistivity values (Table 1). The decaying curve of the graph also gives the impression that the groundwater potential could be high at deeper depths. The first and second layer resistivities are moderately low, and this suggests that the overburden is not a strongly consolidated weathered zone. Therefore, surface waters and runoffs can easily infiltrate the subsurface to recharge the aquifer (Gray and Norum, 2013). The depth of access of $39.88 \mathrm{~m}$ however, makes it susceptible to contamination from surface contaminants. However, if a borehole was drilled to deeper depths this situation could be averted. Groundwater potential at this point is thus expected to be high at greater depths, hence, the point was recommended for borehole drilling to a minimum depth of $60 \mathrm{~m}$. This point was, however, not drilled as the point A80 (see below) was found to rank better.

\section{VES Point A80, Akurakan}

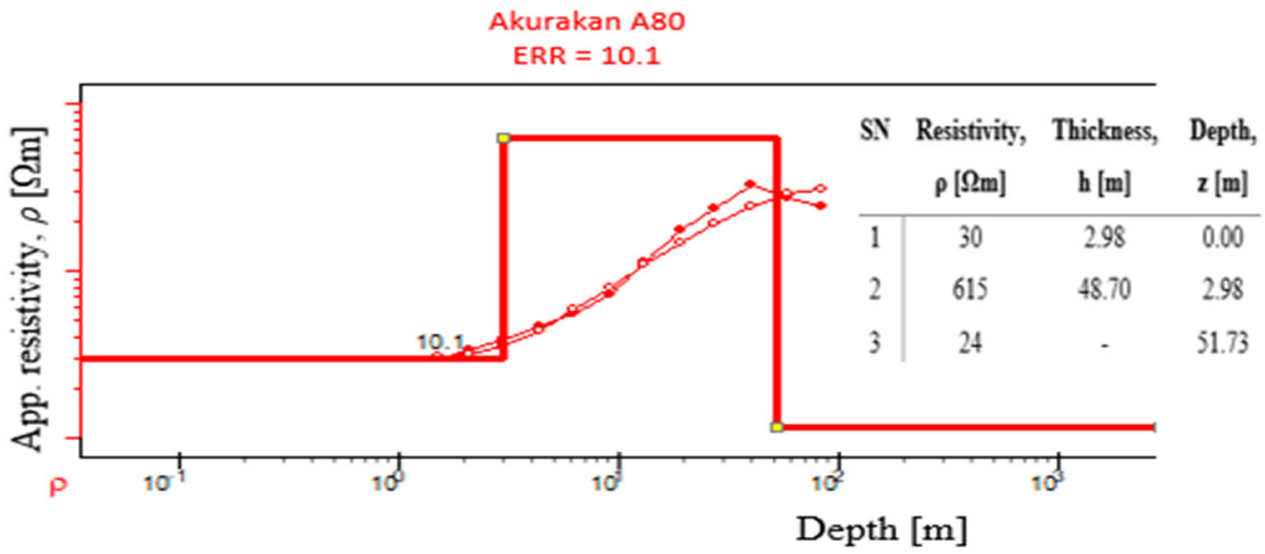

Fig. 9: VES modelled curve for station A80, Akurakan

This station was ranked above station A50 and was therefore drilled. Due to the decaying nature of the graph (Fig. 9), the aquifer was projected to be intercepted at a greater depth than the depth of probe. Generally, rising curves suggest the presence of consolidated rock while decaying curves are promising zones of porous or fractured rocks which are suitable for groundwater development (Manu et al., 2019). Hence, $70 \mathrm{~m}$ depth was recommended 
as the drill depth; however, at a depth of $68 \mathrm{~m}$ the borehole gave a test yield of $1.14 \mathrm{~m}^{3} / \mathrm{h}(19 \mathrm{~L} / \mathrm{min})$. The overburden was composed mainly of laterite and moderately weathered phyllites with a semi hard phyllite bedrock. Groundwater potential in phyllite bedrocks is usually high (Fashae et al., 2014).

\subsubsection{Results of soil resistivity survey from the Nana Ameyaw Community}

\section{Nana Ameyaw A70}

$E R R=29.1$

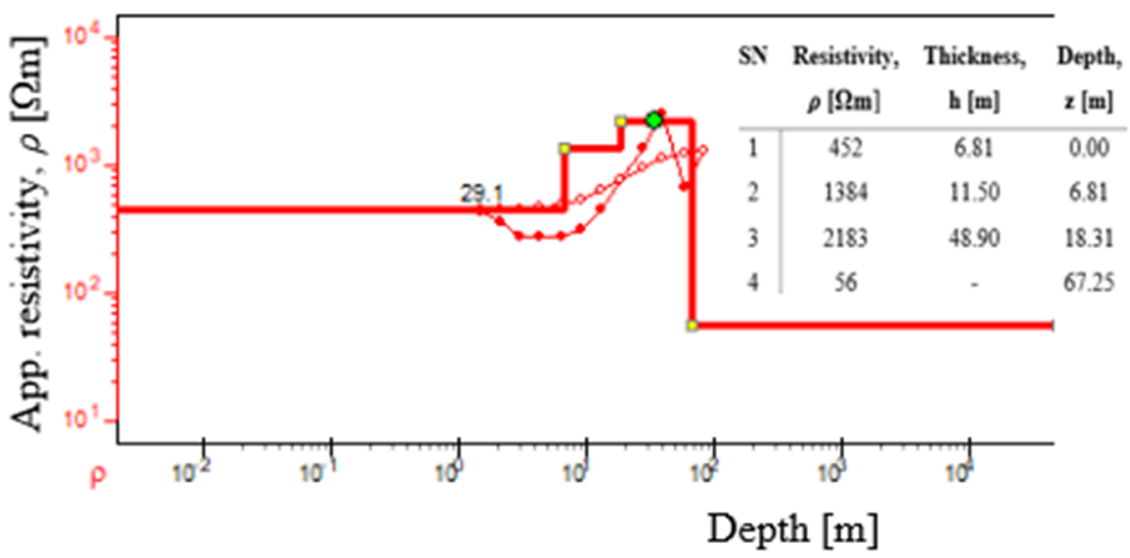

Fig. 10: VES modelled curve for station A70, Nana Ameyaw

Like the other communities, two VES points (A70 and A120) were probed in this community. The presence of the fresh-looking baobab trees a few distance away from the VES points suggested a high groundwater potential at station A70. Three quantities (the basement rock resistivity, overburden thickness and nature of the modelled curve) are usually considered in determining a suitable site for borehole drilling (Manu et al., 2019; Bienibuor et al., 2016; Bayewu et al., 2018). All these quantities were considered, making this site very suitable for drilling. The overburden of about $67 \mathrm{~m}$ (Fig. 10) is an added advantage to this site because, at this depth the aquifer is less susceptible to pollution (Adeniji et al., 2013; Ariyo et al., 2011; Bayewua et al., 2018). This site was therefore recommended for drilling.

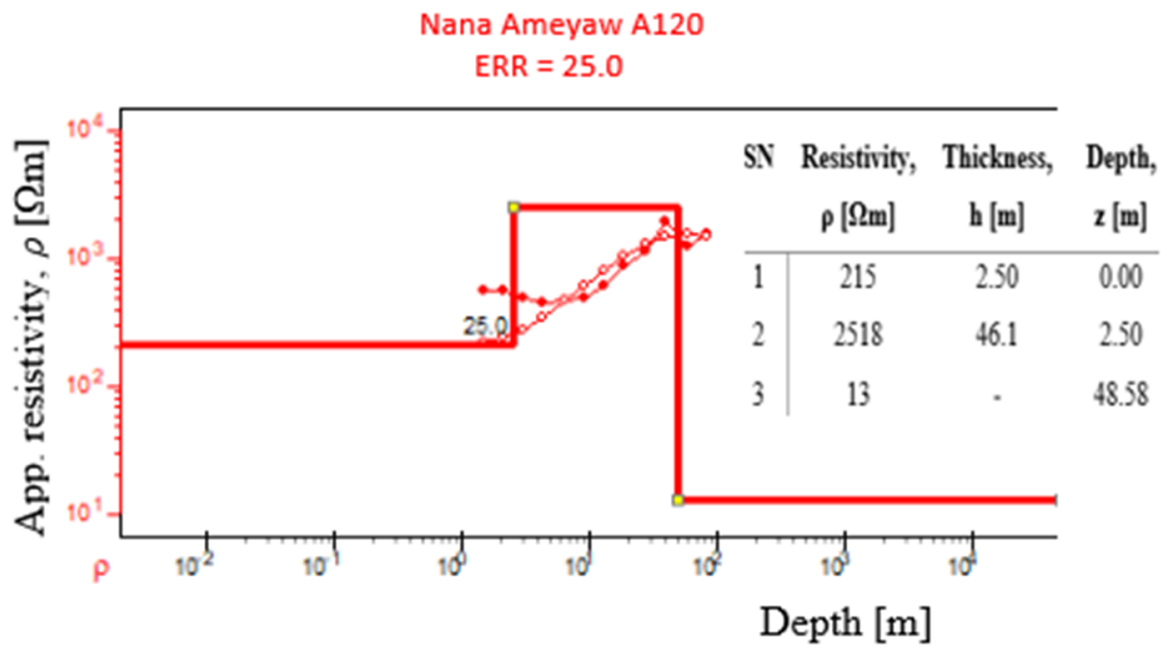

Fig. 11: VES modelled curve for station A120, Nana Ameyaw

Compared to point A70, groundwater prospect at station A120 was equally expected to be high. Apart from the very low basement rock resistivity, the graph at this point (Fig. 11) displayed a decaying curve, an indication that at greater depths groundwater potential could still be high. Though the depth to the aquifer (48.58 m, Fig. 11) was good, it was less than that of A70. Hence, in terms of the overburden point A70 was preferred to point A120. However, based on the proximity to the waste site deposit in the community and the voice of the community counted, as to where they wanted the borehole to be sited, A120 was ranked above A70. Therefore, the borehole was drilled at point A120 to a depth of $55 \mathrm{~m}$ (even though $60 \mathrm{~m}$ was recommended), yielding $24 \mathrm{~m}^{3} / \mathrm{h}(400 \mathrm{l} / \mathrm{m})$. Soil types intercepted included quartz, laterite, decomposed to slightly weathered phyllites and a heavily fractured phyllite bedrock.

\section{Conclusion}

Though works have been done in the past to deal with the water crisis situation in the Sunyani West District of 
Ghana, lots of rural communities in the district still depend on unsafe water sources (Nabunnya et al., 2012). A research conducted by the Community Water and Sanitation Agency (CWSA) and the International Rescue Committee (IRC) in the then Brong Ahafo Region of Ghana indicated that there were many cases of waterborne diseases in the Sunyani West District of the region, arising from the reliance of inhabitants on unsafe surface water sources (CWSA and IRC, 2012) due to previous unsuccessful borehole siting approaches. This paper explored groundwater potential sites in a few communities in the Sunyani West District of the Bono Region of Ghana using two complementary geophysical methods for the first time in the study area.

The Adwinsa, Akurakan and Nana Ameyaw communities are part of the many rural communities in the Sunyani West District where the people have problems with potable water. Many of these rural communities depend either wholly or majorly on streams and rivers for all their water needs (Sakyi et al., 2018; Attiogbe and Nkansah, 2017). Some have only one borehole serving the entire community to complement their water needs from the streams or rivers. The water crisis situation has affected many dwellers of these rural communities in many ways, from different water related diseases to developmental issues (Entsua-Mensah et al., 2007; Mainoo et al., 2012; Anane, 2013).

Sources of water in the Adwinsa, Akurakan and Nana Ameyaw communities are streams/rivers (some of which are ephemeral), and a privately owned hand-dug well in Adwinsa. Drinking water from such sources leaves inhabitants vulnerable to all kinds of diseases.

Previous works in different parts of the Bono Region on groundwater exploration resulted in the drilling of some boreholes in some communities of the district (Sikah et al., 2016; Kortatsi and Quansah, 2004). These boreholes however, are not only insufficient to solve the water crisis situation in the district, but some have dried up with time.

This paper located six groundwater potential sites (Table 2) which were identified and selected for borehole drilling.

Table 2: Selected sites for drilling.

Community GPS coordinates

$\begin{array}{cccc}\begin{array}{l}\text { Elevation } \\ \text { (amsl) }\end{array} & \begin{array}{c}1^{\text {st }} \text { ranked } \\ \text { VES point }\end{array} & \begin{array}{c}2^{\text {nd }} \text { ranked } \\ \text { VES point }\end{array} & \begin{array}{c}\text { Recommended } \\ \text { drill depth }[\mathrm{m}]\end{array} \\ 282 & \text { A300 } & \text { A170 } & 60 \\ 323 & \text { A80 } & \text { A50 } & 70 \\ & \text { A120 } & \text { A70 } & 60\end{array}$

Nana Ameyaw $\quad 7.39992^{\circ} \mathrm{N}$

$2.47097^{\circ} \mathrm{W}$

The selection of these potential sites was based on three major factors. These were, the bedrock resistivity, the thickness of the overburden and the nature of the apparent resistivity-depth plot. The selected aquifers had depths ranging from 40 to $67 \mathrm{~m}$. However, drilling depths recommended for the three communities were 60, 70 and $60 \mathrm{~m}$ for Adwinsa, Akurakan and Nana Ameyaw, respectively. In addition, all the bedrock resistivities were within that of fresh groundwater resistivity value range of 10 to $100 \Omega \mathrm{m}$ (Telford et al., 1990). The nature of their apparent resistivity-depth plots indicated decaying curves or curves that showed signs of potential decay. In effect, all the aquifer loci located showed promising signs of good groundwater potentials. Three wet boreholes, one for each community, were drilled with yields of $12 \mathrm{~m}^{3} / \mathrm{h}, 1.14 \mathrm{~m}^{3} / \mathrm{h}$ and $24 \mathrm{~m}^{3} / \mathrm{h}$ for Adwinsa, Akurakan and Nana Ameyaw communities respectively. The overburden for Adwinsa was found to comprise laterite (with reddish topsoil). The overburden at Akurakan community was found to be made up of a mixture of laterite and moderately weathered phyllites and a mixture of quartz, laterite and decomposed to slightly weathered phyllites at the Nana Ameyaw community. In all three communities the basement rock was found to be phyllitic. This paper, through its effective borehole siting has been able to drastically reduce the water crisis situation in the three communities in the Sunyani West District. In addition, given the fact that groundwater potentials in phyllites are high and sustainable, borehole drillers in adjourning rural communities in the district can apply the knowledge of this geological setup (which is not expected to be significantly different) in future drilling campaigns

This integration of ground conductivity and electrical resistivity techniques was found to be effective in characterising the near-surface heterogeneities.

Adjourning districts of the Sunyani West District such as the Sunyani Municipal, the Berekum Municipal, etc. would likely benefit from a successful outcome of this paper since they share some geological formations. Additionally, the outcome of this paper would give drillers in such districts, an idea of the depth of access to groundwater

\section{References}

Acworth, R. \& Dasey, G. (2003). Mapping of the hyporheic zone around a tidal creek using a combination of borehole logging, borehole electrical tomography and cross-creek electrical imaging, New South Wales, Australia. Hydrogeology Journal 11, 368-377 
Anane, E. T. (2013). Environmental Challenges Facing a Growing City: Sunyani Case Study. Consilience, (10), 180-190.

Anechana, R. et al. (2015). Electromagnetic Method and Vertical Electrical Sounding for Groundwater Potential Assessment of Kintampo North Municipality of Ghana. Journal of Environment and Earth Science, 5(12), 916.

Ariyo, S. O., Folorunso, A. F. \& Ajibade, O. M. (2011). Geological and geophysical evaluation of the Ajana area's groundwater potential, southwestern Nigeria. Earth Sciences Research Journal, 15(1), 35-40.

Attiogbe, F. \& Nkansah, A. (2017). The impact of mining on the water resources in Ghana: Newmont case study at Birim north district (new abirem). Energy Environ. Res., 7(2), 27-36.

Bayewu, O. O. et al. (2018). Assessment of groundwater prospect and aquifer protective capacity using resistivity method in Olabisi Onabanjo University campus, Ago-Iwoye, Southwestern Nigeria. NRIAG Journal of Astronomy and Geophysics, 7(2), 347-360.

Beeson, S. \& Jones, C. R. C. (1988). The combined EMT/VES geophysical method for sitting boreholes. Groundwater, 26 (1) 54-63

Bienibuor, A. K. et al. (2016). The use of electromagnetic and electrical resistivity methods in assessing groundwater resource potentials in Adoe, Sunyani, Ghana. International Journal of Scientific and Technology Research. 5(9), $166-170$.

Buttinelli, M. et al. (2011). The geo-database of caprock quality and deep saline aquifers distribution for geological storage of CO2 in Italy. Energy, 36(5), 2968-2983.

Chegbeleh, L. P. et al. (2009). Electromagnetic geophysical survey for groundwater exploration in the voltain of Northern Ghana. Journal of environmental hydrology, 17, $1-16$.

CWSA \& IRC. (2012). Water Sector Scan of the Sunyani West District - Brong Ahafo Region. Triple-S Project.

Dapaah-Siakwan, S. \& Gyau-Boakye, P. (2000). Hydrogeologic framework and borehole yields in Ghana. Hydrogeology Journal, 8(4), 405-416.

Dieter, C. A. et al. (2018), "Estimated use of water in the United States in 2015 (No. 1441). US Geological Survey.

Dinka, M. O. (2018). Safe Drinking Water: Concepts, Benefits, Principles and Standards. Water Challenges of an Urbanizing World. IntechOpen, London, 163-181.

Entsua-Mensah, R. M. et al. (2007). Assessment of community water and sanitation in Ghana. ATPS Working Paper Series No. 45.

Fashae, O. A. et al. (2014). Delineation of groundwater potential zones in the crystalline basement terrain of SWNigeria: an integrated GIS and remote sensing approach. Applied Water Science, 4(1), 19-38.

Fienen, M. N. \& Arshad, M. (2016). The international scale of the groundwater issue. In Integrated Groundwater Management. Springer, Cham., 21-48

Grinevskii, S. O. (2014). The effect of topography on the formation of groundwater recharge. Moscow University Geology Bulletin, 69(1), 47-52.

Gyau-Boakye, P. \& Dapaah-Siakwan, S. (2004). Groundwater as a source of water supply in Ghana. Journal of Applied Science and Technology, 5(1): $77-86$.

Gyamfi, E. T. et al. (2012). Chemical analysis of potable water samples from selected suburbs of Accra, Ghana. Proceedings of the International Academy of Ecology and Environmental Sciences. 2(2): 118 - 127.

Jayeoba, A. \& Oladunjoye, M. A. (2015). 2-D Electrical Resistivity Tomography for Groundwater Exploration in Hard Rock Terrain. International Journal of Science and Technology, 4(4), 156-163.

Jury, W. A. \& Vaux Jr, H. J. (2007). The emerging global water crisis: managing scarcity and conflict between water users. Advances in agronomy, 95, 1-76.

Kumar, D. (2012). Efficacy of electrical resistivity tomography technique in mapping shallow subsurface anomaly. Journal of the Geological Society of India, 80(3), 304-307

Kortatsi, B. K. \& Quansah, J. (2004). Assessment of groundwater potential in the Sunyai and techiman areas of Ghana for urban water supply. West African Journal of Applied Ecology, 5(1).

Loke, M. H. (2000). Electrical imaging surveys for environmental and engineering studies. A practical guide to 2D and 3-D surveys. 1-4. (Copyright 1997, 1999, 2000).

MacDonald, A. M., Davies, J. \& Ó Dochartaigh, B. É. (2001). Simple methods for assessing groundwater resources in low permeability areas of Africa. British Geological Survey, Natural Environment Research Council. Commissioned Report CR/01/168N

Mainoo, P. A. et al. (2012). Evaluation of aquifer characteristics of Voltaian Sedimentary rocks in the Brong Ahafo Region of Ghana. Journal of the Ghana Science Association, 14(2), 73-85.

Manu, E. et al. (2019). Application of vertical electrical sounding for groundwater exploration of Cape Coast municipality in the Central Region of Ghana. Arabian Journal of Geosciences, 12(6), 196.

McNeill, J. D. (1980). Electromagnetic Terrain Conductivity of Measurements at Low Induction Numbers. Geonics Ltd. Technical Note TN-6.

Mostafa, M., Anwar, M. B. \& Radwan, A. (2018). Application of electrical resistivity measurement as quality 
control test for calcareous soil. HBRC journal, 14(3), 379-384.

Muchingami, I. et al. (2012). Electrical resistivity survey for groundwater investigations and shallow subsurface evaluation of the basaltic-greenstone formation of the urban Bulawayo aquifer. Physics and Chemistry of the Earth, Parts A/B/C, 50, 44-51.

Ndlovu, S. et al. (2010). Mapping Groundwater Aquifers Using Dowsing, Slingram Electromagnetic Survey Method and Vertical Electrical Sounding Jointly in the Granite Rock Formation: A Case of Matshetshe Rural Area in Zimbabwe. Journal of Sustainable Development in Africa 12(5).

Nyquist, J., Freyer, P. \& Toran, L. (2008). Stream bottom resistivity tomography to map ground water discharge. Ground Water 46, 561-569

Olasehinde, P. I. \& Bayewu, O. O. (2011). Evaluation of electrical resistivity anisotropy in geological mapping: A case study of Odo Ara, West Central Nigeria. African Journal of Environmental Science and Technology, 5(7), 553-566.

Palacky, G. J., Ritsema, L. L. \& De Jong S. J. (1981). Electromagnetic prospecting for Groundwater in Precambrian terrain in the Republic of Upper Volta. Geophysical Prospecting, 29, 932-955.

Park, J. et al. (2016). Analysis on caprock and aquifer properties related with leakage during CO2 storage. Geosystem Engineering, 19(4), 188-196.

Sakyi, P. O., Bienibuor, A. K. \& Akuamoah, R. K. (2018). Assessing the Physicochemical Parameters of Water Sources in the Fiapre Vicinity, a Suburb of Sunyani in the Brong Ahafo Region of Ghana. International Journal of Advances in Scientific Research and Engineering, 4(9), 153 - 163.

Sathish, S. et al. (2011). Assessment of seawater mixing in a coastal aquifer by high resolution electrical resistivity tomography. International Journal of Environmental Science and Technology, 8(3), 483-492.

Siemon, B., Christiansen, A. V. \& Auken, E. (2009). A review of helicopter-borne electromagnetic methods for groundwater exploration. Near Surface Geophysics, 7(5), 629-646.

Sikah, J. N. et al. (2016). Groundwater Exploration using 1D and 2D Electrical Resistivity Methods. Journal of Environment and Earth Science, 6(7), pp.55-63.

Srinivasan, V. et al. (2012). The nature and causes of the global water crisis: Syndromes from a meta-analysis of coupled human-water studies. Water Resources Research, 48(10).

Telford, W. M., Geldart, L. P. \& Sheriff, R. E. (1990). Applied Geophysics. Cambridge University Press. 2nd edition. $792 \mathrm{p}$

Ugya, A. Y., Ajibade, F. O. \& Ajibade, T. F. (2018). Water Pollution Resulting from Mining Activity: An Overview. In Proceedings of the 2018 Annual Conference of the School of Engineering and Engineering Technology (SEET). The Federal University of Technology, Akure, Nigeria, 17-19.

UNICEF/ WHO. (2012). Highlight need to further reduce gaps in access to improved drinking water and sanitation. Accessed on $8^{\text {th }}$ May, 2019.

Vilarrasa, V., Olivella, S. \& Carrera, J. (2011). Geomechanical stability of the caprock during CO2 sequestration in deep saline aquifers. Energy Procedia, 4, 5306-5313.

Watkins, K. (2006). Human Development Report 2006-Beyond scarcity: Power, poverty and the global water crisis. UNDP Human Development Reports (2006). 